\title{
Narratology and Orality in African Biblical Hermeneutics: Reading the story of Naboth's vineyard and Jehu's revolution in light of Intsomi yamaXhosa
}

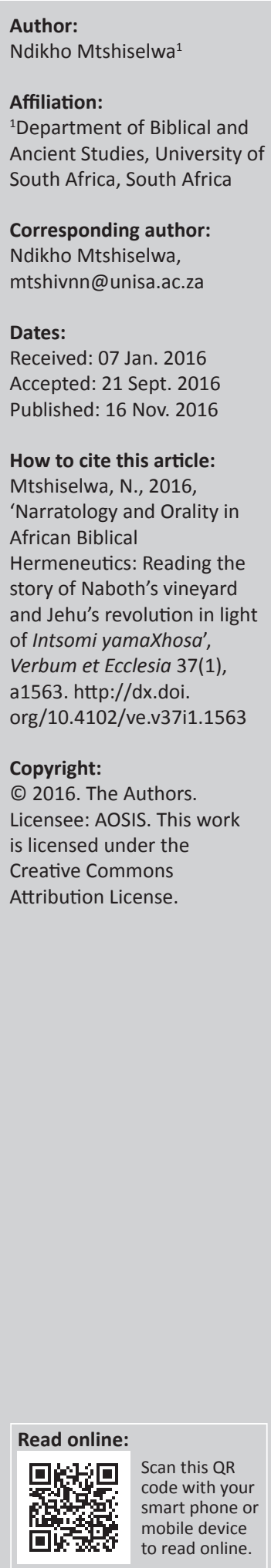

On the issue of methodology, oral literature has been decisive in the interpretation of the Hebrew Bible in Africa. For instance, Madipoane Masenya (ngwan'a Mphahlele) convincingly employed the folktale of the 'Rabbit and the Lion' in her interpretation of the Bible. That Narratology and Orality in African Biblical Hermeneutics is a rarely researched area within biblical scholarship provides room for further studies in this area. This article argues that the reading of the Deuteronomistic story of Naboth's vineyard and Jehu's revolution in the light of Intsomi yamaXhosa [the folktale of the Xhosa people] illustrates how biblical interpretation in Africa could be informed by Orality and Narratology. This article examines the light that the socio-economic function of the story of Naboth's vineyard and Jehu's revolution would throw on the function of the folktale of Intsimi yeenyamakazana, and vice versa. Furthermore, the present article probes the socio-economic implications that can be drawn from biblical and Xhosa Orality and Narratology for post-apartheid South Africa.

Intradisciplinary and/or interdisciplinary implications: This article draws on the indigenous knowledge system, namely Xhosa Narratology and Orality, to interpret Old Testament texts with a view to offering liberating socio-economic possibilities for poor black people in South Africa.

\section{Introduction}

\section{Xhosa Orality and Narratology: A theoretical framework}

\begin{abstract}
Kwathi ke kaloku yaziinyamakazana zonke, zazilima intsimi zemka zaya kutya amaqgabi ezintabeni. Zabuya zayihlakuhlakula. Zemka zaya kutya amagqabi ezintabeni. Zabuya zisiya kuhlola. Zathi zisekude zabona isisi phakathi entsimini, zathi: 'Madoda kuza kuthiwani?' Zahlala phantsi zonke kwathi nqwadada; kwathiwa, 'Khawuye wena wakwaMvundla.' Wathi la-cu, la-cu waya wema emvikweni wathi, 'Ungubanina wena ukuloontsimi yeenyamakazana zonke; zayilimalima zayihlakuhlakula zemka zaya kutya amgqabi ezintabeni?' Yathi, 'Ndim mna Sikhabankungu ngonyawo! Ndingasuke ndithi apha kwimivundla kuthi tha ilanga,' wagqotsa umvundla. Kwathiwa, 'Kha uye wena wakwaNyhwagi.' Ufike naye wamemeza esithi, 'Ungubanina wena ukuloo ntsimi yeenyamakazana zonke, zayilimalima, zayihlakuhlakula zemka zaya kutya amagqabi ezintabeni?' 'Ndithi ndim mna Sikhabankungu ngonyawo, ndingasuke ndithi apha kooziNyhwagi kuthi tha ilanga.' Yabaleka iNyhwagi yazaphula. Zathulisana zonke zaphela zisenza loo nto, kwasala intwana ebhityileyo, neyeyeke kakhulu, ekuthiwa nguFudwana. Kwathiwa, 'Kuza kuthiwani ngoku, Madoda?' Zathi ezinye makuye uFudwana, ezinye zadela zancama zathi, 'E-h-e, nibona ngakubona kunjanina, madoda, nithi laa nto niyiva nje ukuthetha kwayo ifanele ooFudwana aba? Sukani, Madoda, niyafeketha. Makuske kuchithakalwe.' Ezinye zajoka zathi, 'Yiyawena, Fudwana.' Wabonakala eswabulula amanya akhe ngokuzolula, zayezisithiezinye, 'Kodwa, kodwa Fudwana uyaphi? Ucinga ukuba ungade wenzeni ubhitye unjenjenje, uva aba bathiyiya? Suka apha, musa ukuya kuzibulalisa, akukwazi nokubaleka.' Wakrwabaza waya ukhekhe yena, wafika wema emvikweni wathi, 'Ungubani wena ukuloo ntsimi yeenyamakazana zonke, zayilimalima, zayihlakuhlakula, zemka zaya kutya amagqabi ezintabeni?' Yathi, 'Ndim mna Sikhabankungu ngonyawo, ndingasuke ndithi apha kooFudwana kuth' ilanga.' Wathi, 'Ndithi mna ungubanina wena ukule ntsimi yeenyamakazana zonke, zayilimalima zayihlakuhlakula, zemka zaya kutya amagqabi ezintabeni?' Watsho ekhawuleza onde ngayo. Wasel' eyibona isoja umbona, waphinda wathi, 'Ndithi mna ungubanina wena ukule ntsimi yeenyamakazana zonke, zayilimalima zayihlakuhlakula zemka zaya kutya amagqabi ezintabeni?' Yala xa ithi, 'Ndithi, ndithi ndithi mna Sikhabankungu ngonyawo,' wakhwela uFudwana kwakhanywana kwayimbuqe, wada uFudwana wayikhama wayibulala; wahlala phantsi watya umbona ebimojile wagqiba, wavakala ezithethela, eyitsho ingomaya kowabo:
\end{abstract}

\section{Thina bo-o-Fu-dwa-na, wo-ngqi-ngqi! \\ Sahla salugeqa wo-ngqi-ngqi}

Note: This article is partially based on the author's thesis of the degree of Doctor of Literature and Philosophy in Biblical Studies (Old Testament) at the University of South Africa, South Africa, with supervisor Prof. M.J. Masenya, received February 2015, available here: http://uir.unisa.ac.za/bitstream/handle/10500/19149/thesis_mtshiselwa_vnn.pdf?isAllowed=y\&sequence=1 
Thina bo-o-Fu-dwa-na, wo-ngqi-ngqi

Sahla salugeqa wo-ngqi-ngqi!

Zathi, 'Uthini, madoda uFudwana? Uthi ulugeqile, Madoda?' Kwowu! Kwathi ukuya kuye zashiyana; zambulela, zimbambazela, zimncoma nokumncoma, zimthutha nokumthutha! (Ndibongo \& Ntloko 1990:74-75)

The Xhosa folktale above, called Intsimi yeenyamakazana [the productive land of the animals], as related by Ndibongo and Ntloko (1990:74-75), may be translated as follows:

Once upon a time, when all the animals were working a field, they suddenly went to the mountains to eat leaves. They came back to work on the field. They left to eat the leaves. They came back to inquire what was happening. From afar, they saw a strange animal (smoke) in the field and said: 'Gentlemen, what are we going to do?' They all set down and said: 'How about you go, Rabbit'. The rabbit hopped and hopped, leaving them, and asked the strange animal: 'Who are you in the field of all the animals? The animals prepared, planted and nurtured the field and thereafter went to eat the leaves in the mountains'. It said: 'It is me who kicks your middle with my feet. I would do that to the rabbits and the sun would rise'. The rabbit ran away. Then the animals said: 'You go, Suricate'. He also arrived and shouted: 'Who are you in the field of all the animals? The animals prepared, planted and nurtured the field and thereafter went to eat the leaves in the mountains'. 'I say to you, I am the one who kicks your middle with my feet; I would do that to the suricates and the sun would rise'. The suricate ran away. Then, all the animals were silenced. However, a thin and weak animal called tortoise remained standing. He asked: 'What are we going to do, fellow men?' Some animals said: 'Let the tortoise go', but the others ended up saying: 'Wow, you are easily convinced, you men. Are you saying that the strange animal, who you heard, is a match for the tortoise? Get away, you men, you are playing games. Let us then disperse'. Others rebelled and said: 'Come, you tortoise'. He (the tortoise) appeared, stretching himself, whilst the others said: 'But, but, you tortoise, where are you going? What do you think you are going to do whilst you are skinny like this? You are listening to the ones who say you can go. Go away. Do not let yourself be killed. You do not even know how to run away'. Driven by stubbornness, the tortoise approached, stood in front of the strange animal and asked: 'Who are you in that field of all the wild animals? They prepared, planted, nurtured the field and went to the mountains to eat the leaves'. It said: 'It is I who kicks your middle with my feet. I would do that to the tortoises and the sun would rise'. The tortoise responded: 'I am asking you: who are you in the field of all the wild animals? They prepared, planted, nurtured the field and went to the mountains to eat the leaves'. The tortoise went faster and approached the strange animal. When he saw the strange animal preparing maize, he repeatedly asked: 'Who are you in the field of all the wild animals, which they prepared, planted and nurtured before going to the mountains to eat the leaves?' When the strange animal started to say: 'I'm saying, I'm saying, I'm saying, it is me who kicks your middle with my feet', the tortoise climbed on top of the strange animal and it was dusty as they fought. Eventually, the tortoise killed the strange animal and subsequently sat down to eat the maize that the strange animal had roasted in the fire. In the end, the tortoise praised himself, singing the family song:

We the tortoises, tapping our feet.

We stood and chopped (the strange animal), tapping our feet.
We the tortoises, tapping our feet.

We stood and chopped (the strange animal), tapping our feet.

The rest of the animals said, 'What are you saying, Tortoise? You are saying that you have chopped the strange animal down, my man?' Wow! All the animals rushed to the tortoise, thanking him, comforting him, applauding him and praising him. (Ndibongo \& Ntloko 1990:74-75, author's own translation)

The folktale is about a group of animals who left their productive land to eat leaves in the mountains. Whilst the animals were in the mountains, an intruder, identified as isisi [an intruder], arrived and confiscated the productive land that belonged to the group of animals. The animals sent the rabbit and suricate to demand their land back from the intruder but failed. Later, in the struggle for the productive land, uFudwana [the tortoise] sacrificed his life and defeated the strange animal. In the end, the group of animals rejoiced because they had regained their land. From a socioanthropological and economic point of view, some remarks about the folktale under consideration are in order. Firstly, it seems that the mode of production employed by the group of animals was communitarian and familial. The connection between a single animal and the rest of animals, who formed a community of animals, termed a 'group of animals' in the folktale, supports the preceding observation. Secondly, the acquisition of land by isisi depicts a dimension of turning a common property, that is, productive land, into a private assert. The behaviour of $i s i s i$ therefore reminds one of an early theorist of capitalism, namely, Hugo Grotius (1583-1645). Based on an interaction with the text of Genesis 1-3, Grotius (2006) argued that:

it is God's will that human beings are 'free', that they make into private property what was once common property, and that the institutions of early capitalism may be seen as part of the divine plan. (pp. 315-321; cf. Boer 2015:15)

Although Grotius made a valid point, I am however drawn to an element of evil in the myth of capitalism that is teased out by Thomas Malthus (1766-1834), because capitalism is synonymous with self-interest and self-enrichment as well as imperialism (cf. Boer 2015:16; Malthus 2004). From a classical economic point of view, particularly drawing on these early theorists of capitalism, Grotius and Malthus, isisi's demand for the communally shared productive land therefore exhibits the ideology of capitalism.

Thirdly, the struggle for the productive land displayed by uFudwana and the defeat of isisi draws to mind Vladimir I. Lenin's (1972:9) statement: 'A bad doctrine is splendidly rectified by a good revolution' (cf. Boer 2015:18). Marxist theory, especially its Leninist adaptation, resonates with the actions of uFudwana. Prior to discussing Leninism, some remarks on the usage of Marxism as a theoretical framework in African Biblical Hermeneutics are warranted. Mosala's black biblical hermeneutic of liberation is guided by the theoretical position of historical materialism, a framework that is associated with Karl Marx. Not only does the framework give priority to social relations, specifically in 
terms of class, race and gender both in the biblical text and the modern context, it similarly advances the interests of the poor (Mosala 1997:57-58). Marxism, a theoretical framework that Mosala adopts, regards the overthrowing of the imperialistic and capitalistic ruling élites by the proletariat as constituting justice in that it seeks to enforce economic equality (Degenaar 1982:11). However, Marxism does not seem to be entirely innocent. Marxism does not completely oppose capitalism, because it is also a theory that is set to take over power with the aim of centralising it within the leadership of the proletariats (Degenaar 1982:27). On the political implications of Marxism, Mosala notes West's remarks thus:

For the oppressed colored (black) peoples, the central problem is not only repressive capitalist regimes, but also oppressive European civilizing attitudes. And even Marxists who reject oppressive capitalist regimes often display oppressive European civilizing attitudes toward colored peoples. In this sense, such Marxists, though rightly critical of capitalism, remain captives of the worst of European culture. (Mosala 2006:134-135; West 1981:256)

It is precisely in light of the preceding remark that I partly depart from Mosala's black biblical hermeneutics of liberation. A theoretical framework that is based on Marxism also has negative traits. Marxism as a theoretical framework is a captive of Europeanness, and for this reason it has been shunned by postcolonial biblical criticism (Boer 1998:24-48). However, it must be noted that Marxist theory has offered biblical studies a valuable tool, particularly with regard to the understanding of the historical mode of production, which enables us to locate our exegetical work within the socio-historical systems in the world of the text's production (cf. West 2011:513-514, 529). A case in point in the theoretical framework under consideration, particularly Leninism, that will assist us in reading the narrative of Naboth's vineyard and Jehu's revolution is partly the issue of 'class conflict'.

In his context, Lenin (1964:385-497) remarked: 'The state is a product and a manifestation of the irreconcilability of class antagonism' (cf. Boer 2015:134). In many a context, whether in the ancient or present period, the dynamics of and contestations between the ruling élite, working class and the poor are noticeable. Although Lenin's (1964:388) revolutionary philosophy on the oppression and exploitation of peasants is commendable, the argument that 'the only way to overthrow the state is to seize control of the state and then use its machinery to crush one's class enemy' is however inconclusive. The argument is based on the view that:

If the state is the product of the irreconcilability of class antagonism; if it is a power standing above society and 'alienating itself more and more from it', it is clear that the liberation of the oppressed class is impossible not only without violent revolution, but also without the destruction of the apparatus of state power which was created by the ruling class and which is the embodiment of this 'alienation'. (Lenin 1964:388; cf. Boer 2015:134)
Violence as means of attaining liberation constitutes an unconvincing approach, particularly when compared with a revolutionary model that is based on a form of democratic process, such as elections. However, worthy of note is the theory on the reconciliation of conflicting classes. As Aglietta (2000:26) argued, the state is 'a mode of social cohesion required by relations of production that divide society into conflicting groups with heterogeneous objectives and unequal possibilities of action' (cf. Boer 2015:135). Based on the preceding argument, the reaction of $u$ Fudwana would be unattractive because reconciliation and settlement on the redistribution of land was an option that was not considered. However, like many an exploited person, the options of uFudwana were limited and a violent revolution became the only convincing method to attain liberation. As John F. Kennedy (1962:1) put it, 'those who make peaceful revolution impossible will make violent revolution inevitable'. In the case of the folktale under investigation, a peaceful revolution preceded the violent revolution, particularly where $u$ Fudwana responded: 'I am asking you: who are you in the field of all the wild animals? They prepared, planted, nurtured the field and went to the mountains to eat the leaves'.

With respect to the South African context, interestingly, black South Africans similarly lost their productive land to the white colonialists. Driven by a desire for self-enrichment, isisi dispossessed them of their land and subsequently excluded the animals who worked the land. The capitalist tendency reminds one of the issues of capitalism in South Africa. What we have in the narrative is a situation of the minority or a single strange animal contributing to the disparities in land ownership and to socio-economic injustice in the field. The majority of the animals became poor because of land dispossession like the black South Africans. In the end, the redistribution of the productive land to the majority of animals who lost the land to isisi constitutes socio-economic justice. However, the tale differs from the issue of land in South Africa because socio-economic justice is yet to be realised by the poor black South Africans. Noteworthy, Klein (2007:196) pointed out that on the one hand staunch Marxists dismissed the African National Congress' policy as 'petty bourgeois', as it was not revolutionary enough to divide the ownership of land among all people. On the other hand, the Leninists held on to Lenin's view that private property must be abolished (Klein 2007:196). The protection of privatisation by the addition of the property rights clause made and still makes land reform virtually impossible (Klein 2007:203). This act of protection also stands in contrast with Leninism.

Inspired by Masenya (ngwan'a Mphahlele)'s (2009:126-150) use of the folktale the 'Rabbit and the Lion' in the interpretation of the Bible, a Xhosa folktale is employed here as a hermeneutical tool to unlock the meaning of biblical texts. In addition, the author of this article probes the light that the socio-economic function of the story of Naboth's vineyard and Jehu's revolution in its pre-industrial context throws on the function of the folktale of Intsimi yeenyamakazana, and vice versa. The preceding functions are discussed under 
but not limited to the following themes: (1) the narrative of Naboth's vineyard in its context, (2) equitable sharing of resources, (3) land dispossession and (4) a revolution betrayed or justice attained? This study partly tests the use of modern post-industrial categories in the interpretation for pre-industrial texts. In the end, the author teases out socioeconomic implications from the biblical as well as Xhosa Narratology and Orality for a capitalist, colonialist and postapartheid South African context.

\section{The narrative of Naboth's vineyard in its context}

Land transactions are evident in the Book of Kings, especially in the Omride dynasty. The text of 1 Kings 16:24 shows that Omri 'acquires the land of Samaria from a personal estate with compensation of two talents of silver' (Nam 2012:10). The price is much higher in comparison to the sale transactions in Genesis 23:16; 2 Samuel 24:42 and Jeremiah 32:9; the land under consideration carried a much higher value since it was located in the future capital city of Israel. The geographic location of Samaria subsequently became important to the economic activities between the Omride dynasty and the Phoenicians. Taking his cue from Omri, Ahab negotiated a transaction with a view to acquire the land as a personal commodity. 1 Kings 21:1-19 suggests that King Ahab made a 'generous offer to Naboth, the owner, seemingly equitable and fair to purchase the land' (cf. Nam 2012:144). It therefore becomes clear that the land was partly viewed as a commodity in ancient Israel. Interestingly, the transaction involving Naboth's vineyard was unsuccessful because land was tied to one's social heritage. As Nam (2012:10) observed, 'Transactions with land suggest its inalienable tie to the patrimonial line, consistent with many well-documented settings in [the] ancient Near East' (cf. 1 Ki 16:24; 21:1-16; 2 Ki $8: 1-6)$. Thus, a familial dimension to the ownership of land is notable.

In the agrarian society of the Israelite monarchy, wealth was inseparable from power (Stansell 2006:96; cf. Heilbroner 1985:45). Often, wealth was easily converted to power and the other way around (Stansell 2006:96; cf. Heilbroner 1962:27, 1985:45; Lenski 1966:229; Malina 1987:359). A case in point is that in the political economy of ancient Israel, especially in traditional, aristocratic preindustrial societies, 'élites who desire wealth exercise their exploitative power over peasants and also compete with other élites for control over the land where peasants live' (Stansell 2006:97). As Stansell (2006:97) noted, the accumulation of wealth and power included the pursuit of owning land, controlling markets and most importantly trade routes, such as the Jezreel Valley. A socioanthropological reading of the ancient Near East thus reveals that the transfer of wealth involved 'the intangibles of rank and honour, power and privilege' (Stansell 2006:93). The idea of the acquisition of wealth in the economy of ancient Israel is therefore not new. For instance, the patriarchal narratives suggest that Abraham was wealthy (cf. Gn 12:5, 6; 13:2; 14:21-24; 20:14-16; 24:35, 53). In that case, to accumulate wealth is equated with 'to gather property' (cf. Gn 12:5). Genesis 31:18 relates wealth to property and livestock, whilst Genesis 36:6 includes family, cattle and property. Abraham's wealth is also typified by the possession of money and precious metals (cf. Gn 13:2) as well as some land, though it is not the entire Promised Land (cf. Gn 20:15). It is clear therefore that the possession of land is inseparable from wealth.

On the issue of land being private property, Boer is sceptical about speaking of private or individual property when referring to the situation in ancient biblical times. However, he does not completely rule out the possibility that certain biblical texts that 'include Abraham's acquisition of the field of Machpelah in Gen 23', 'Boaz's acquisition from Naomi of both land and woman in Ruth 4', as well as 'Ahab and Naboth's vineyard in $1 \mathrm{Kgs} \mathrm{21}$ ' in actual fact refer to hlhn [a personal possession] (Boer 2015:230-231). In Deuteronomistic tradition (D), land promised to Israel is given as hlhn [a personal possession] (Nihan 2007:66, cf. n. 241). In D, hlhn [a personal possession] is often improperly rendered as 'inheritance', whereas the concept refers to some form of 'entitlement or rightful property of a party that is legitimised by a recognised social custom, legal process, or a divine character' (Nihan 2007:66-67, especially n. 241). Thus, it is not surprising that the Deuteronomistic historian employed the term hlhn [a personal possession] in the story of Naboth's vineyard (1 Ki 21:3, 4), revealing the perception of land as a personal possession. In other instances, namely Deuteronomy 15:4; Joshua 1:6, 24:32; Exodus 15:15, 17 and Genesis 48:6, hlhn [a personal possession] is used with reference to the promise of land made to the Patriarchs, which suggests that there was an ideological contestation over the idea that the land was a personal possession. Given D's motif of the integration of the concerns of the people of Golah in the Persian period based on class, including the disparity between the urban and rural dwellers, the presentation of land as a personal possession is not surprising (Römer 2005:175, 177). Scholars such as Knight (2011:202) and recently Boer point out that throughout the Monarchic, Neo-Assyrian and NeoBabylonian periods and even during the Persian period, large portions of agricultural land that produced wealth were owned by the rich and powerful élites who resided in the cities. The apparent distinction between the ownership of land in the village and in the cities suggests that D preferred the rich élites to the poor to the point of legitimising the personal accumulation and ownership of land (Douglas 1999:243; Kinsler \& Kinsler 1999:17). Clearly, D was sympathetic to the ideology of classism, which commoditised and privatised land in favour of the rich. The usage of $h l h n$ [a personal possession] in D texts as well as in texts that were influenced by D probably served the purpose of supporting and justifying the privatisation (personalisation) of land. No doubt, the Deuteronomistic narrative of Naboth's vineyard contains a feature of personalisation and commoditisation of productive land. 


\section{Equitable sharing of resources}

Prior to the loss of land to an intruder, namely isisi, the animals equitably shared the crops from the field. Instead of being individualistic, the animals collectively worked and mutually benefited from the use of their productive land. Thus, the Xhosa folktale under consideration seems to advance an idea of equitable sharing of resources that is related to the ideology of socialism. Interestingly, socialism is associated with Marxism. Degenaar (1982) views Marxism as:

A theory based on the views of Karl Marx, according to which society is structured according to the basic relationships towards the means of production, dividing society into two classes; the owners and the workers, and resulting in an exploitative and alienated situation which can only be overcome by a revolution in which the state as the coercive instrument of the propertied class is overthrown by the proletariat. (p. 11)

Not only does the preceding view reveal that, for Marxists, overthrowing the imperialistic and capitalistic ruling élites constitutes justice in that it seeks to enforce economic equality, it equally upholds the idea of equitable sharing of resources (cf. Degenaar 1982:11). In a socialist setting, priority is placed on the interest of the community rather than on individual interest. Thus, the equitable distribution of crops among the animals is related to the ideology of socialism. It is clear that the folktale of Intsimi yeenyamakazana promotes a communitarian and familial mode of production, which is caricatured in the communal ownership of the field (productive land), as opposed to individualistic and privatised ownership. The idea of the sharing of resources that we are confronted with in the folktale of Intsimi yeenyamakazana makes one wonder whether the story of Naboth's vineyard equally exhibits such an idea.

The reading of Naboth's refusal to sell the land particularly in light of Marxist theory is yet to be exhausted. The text of 1 Kings 21:3 shows that Naboth refused to sell the field to Ahab mainly because of his understanding of land as an inheritance and a birthright. As Brueggemann (1975:356) rightly perceived:

while Ahab believes that persons, especially royal persons, can own and possess and even seize land, Naboth holds to the notion, surely primitive by contrast, that persons have rootage in and belong to the land. (cf. Brueggemann 2002:94; Mafico 2012:242; Volschenk 2004:634)

By implication, Naboth held the view that land had a history that linked him to his family. Naboth's vineyard belonged to his family and not just to him (Mtshiselwa 2014:217). In a case in which the land belongs to the family, the idea of communal and familial ownership of the land as opposed to individualistic ownership that is embedded in the folktale of Intsimi yeenyamakazana may fit into Naboth's story. The point that Naboth's family probably benefited from the use of the vineyard reveals an element of a communitarian and familial mode of production that insists that people should equitably share the produce of the land. Although the text does not explicitly state that Naboth shared the crops with his family, it is unlikely that the family members did not benefit from the use of the vineyard, especially when the land belonged to the whole family.

A cardinal question to ask is: Could it be that family members benefited from the use of land in ancient Israel, particularly from the perspective of land ownership, as may be revealed in the Old Testament texts? The Ruth scroll reveals that not only Boaz's family harvested from his field, but also Ruth, who was about to be part of the family. In Ruth 2:9, Boaz directs Ruth to glean with the Israelite women workers, revealing the way Ruth shared in the harvest. As Brenner (1999:160) argued, Ruth may not be viewed as an agricultural worker as she was neither employed by Boaz nor received a wage from him. Thus, Ruth gleaned in the familial capacity. Significantly, the communitarian and familial mode of production as well as the Israelite policy on land, specifically with regards to the issue of redemption of land in ancient Israel, sought to alleviate poverty. The redemption of land and poverty in the book of Ruth, which is linked to the Israelite Jubilee legislation (cf. Lv 25; Rt 4), supports the view that the land policy sought to alleviate poverty (cf. Masenya [ngwan'a Mphahlele] 2004:46-59, 2010:269). To the latter view on poverty alleviation, Fischer (1999) remarked:

It is difficult to reconstruct the concept of redemption in the book of Ruth. In buying Naomi's strip of field (4:3-9), Boaz is obviously referring to the regulation of Lev 25:23-24 that aims at preserving the share of land for impoverished landowners. The redemption (Lev 25; cf. Jer 32, from v.8) is nowhere connected with the levirate in the Torah. Both laws relate to each other by referring to the inalienable claim to an estate in the Promised Land, which is to be guaranteed through kin solidarity. (p. 39)

At issue here, as well as in the narrative of Naboth's vineyard, is the preservation of the share of land for impoverished landowners. In a case in which the land is lost, the family would become poor. Olojede (2013:764-767) teases out the case of a Shunemite woman who not only experienced the loss of land but also hunger, that is, poverty. The Deuteronomistic historian $(\mathrm{DH})$ recounts that the Shunemite woman cried out to the king for her land in 2 Kings 8:1-6. However, 'it is remarkable that the women approached the king (or the prophet) to state their case and to demand not only retributive but distributive justice' (Olojede 2013:767768). Eventually, according to the $\mathrm{DH}$, the land that belonged to the Shunemite woman was redistributed to her, thus confirming that in the history of the Israelites, women not only owned productive land but also experienced poverty. In a context in which women like the Shunemite woman lost land and subsequently became poor, the preservation of the share of land for impoverished landowners became critical.

Worthy of note, therefore, is the point that Xhosa Orality and Narratology, and more importantly the folktale of Intsimi yeenyamakazana, presents to the modern reader of the Hebrew Bible (HB) a confrontation with the idea of equitable sharing of resources. In other words, the modern South African reader of the Naboth narrative would understand it in light 
of the folktale under consideration. However, Ahab's action exhibits a tendency to self-enrichment, which stands in contrast to the communitarian and familial mode of production and more importantly is an idea that refutes the equitable sharing of economic resources.

\section{Land dispossession}

1 Kings 16:39-31 provides evidence of negative judgements directed at Ahab. The latter is mainly 'because of his marriage ... to Jezebel of Sidon' (Schmid 2012:76). A case in point here is that King Ahab receives a negative judgement because of his adaptation of a foreign god, Baal, who was imported from Phoenicia together with Jezebel. No doubt, substantive judgemental texts in the Book of Kings, such as 1 Kings 16:25-26; 29-31; 22:51-52 and 2 Kings 10:28-31, contain a cultic foregrounding (cf. Schmid 2012:75). The condemnation of both the Omride and Jehu dynasties 'attributed the fault for the national catastrophe to the primary persons responsible, the kings', in other words, 'because Judah has, therefore we must assume that the kings failed, and not the other way around' (Schmid 2012:117). Worthy of note is the development of Genesis to 2 Kings:

first of salvation history (Genesis-Joshua), and then the history of perdition (Judges-2 Kings), with the salvation history culminating in the gift of the land and the history of perdition ending with the loss of the land. (Schmid 2012:161)

Although there is a cultic foregrounding in the criticism of King Ahab, the loss of land is the crisis that is attributed to the kings in ancient Israel, including King Ahab. In other words, not only is Ahab condemned because of his implication in the worship of Baal, but he also receives a negative judgement because of the manner in which he dispossessed Naboth and his family of their land.

Furthermore, worthy of consideration is Fritz's argument that:

the intention of the story is not to show that Ahab has taken possession of the vineyard for his own use by unlawful means, but rather that the kingship of Israel has removed itself from law and order to the extent where even a judicial murder and the shedding of innocent blood are not ruled out. (p. 211)

The point here is that the text by and large displays King Ahab's failure to uphold the law of YHWH. He (Fritz 2003) substantiates the argument by saying:

With Jezreel lying on a plain, the cultivation of vines nearby is rather unlikely: vineyards would usually be planted on hill terraces, and we ought to conclude that the story does not rest on historical precedents but instead is a fictional example of royal despotism. (p. 211)

Fritz's view is weakened by the excavations at Samaria (modern Seastiyeh), which date the 'first major building phase to early Iron 11, reasonably attributed to the Omride dynasty' (Nam 2012:144). In addition, the Jezreel Valley and the coastal plain were pivotal to the economic development of the Eastern Mediterranean littoral and the Omride dynasty's economic partnership with Phoenicia. Furthermore, the verb ירָש [take possession] renders the view that 'the intention of the story is not to show that Ahab has taken possession of the vineyard for his own use by unlawful means', is inconclusive (cf. Fritz 2003:211). This holds true because the verb ירָּ denotes a forceful 'taking of possession', which is in the 'sense of acquire by conquest, dispossess, and drive out; also in the hiphil it can mean "to make poor"' (Boer 2015:172n72). What we have therefore in the narrative of Naboth's vineyard is land dispossession.

Regarding the story of Naboth's vineyard, Volschenk interestingly highlights an element of self-indulgent consumerism in Ahab. 'This means that Ahab was more interested in the accumulation of assets - the productive land - and less on Naboth's dependence on land for his economic wellbeing' (Mtshiselwa 2014:217). Thus, a critical question to ask is: can we detect a capitalist tendency to selfenrichment in Ahab? As Mtshiselwa (2014:218) observed, 'instead of taking Naboth's interest into account, Ahab acted out of self-interest and became responsible for Naboth's land loss and death'. In the context of the Omri dynasty, the political figures (e.g. Omri) often enriched themselves by purchasing land for private ownership (Mtshiselwa 2014:215). Based on Malthus (2004) and Boer's (Boer 2015:16) observation of an element of evil in the myth of capitalism, which is characterised by self-interest and self-enrichment as well as imperialism, as opposed to the sharing of resources, it makes sense to view Ahab's appropriation of Naboth's vineyard as resonating with the evil of capitalism. It is thus no exaggeration to argue that Ahab's actions bear elements of capitalism and privatisation of a productive asset, the land. Ahab's intention was to exclusively own the productive land for the purpose of self-indulgence. The view that Ahab's intentions were motivated by the desire to exclusively own Naboth's vineyard and a probable capitalist tendency to selfenrichment is further supported by the DH's use of the term hlhn [a personal possession] in the story of Naboth's vineyard (cf. $1 \mathrm{Ki} 21: 3,4)$, which shows that the land was viewed as a personal possession. Furthermore, as mentioned, in the political economy of ancient Israel, a traditional, aristocratic pre-industrial society, the élites, such as Ahab, who desired wealth exercised their exploitative power over peasants in order to gain control over the land for personal reasons (Stansell 2006:97). From a socio-anthropological point of view, desire on the part of Ahab to attain more power may not be ruled out in his appropriation of Naboth's vineyard, especially in the agrarian society of the Israelite monarchy where wealth was inseparable from power (Stansell 2006:96; cf. Heilbroner 1985:45). Therefore, Ahab did not have the interest of Naboth at heart, but his own self-interest in accumulating more power and wealth.

Based on Cone (2007:52, 2011:160) and West's (2014:2) view that biblical text and modern narratives (and contexts) should cast light on each other, it becomes important to investigate the way the folktale of Intsimi yeenyamakazana could be interpreted in the light of 1 Kings 21:1-29. As mentioned above, driven by a desire for self-enrichment, isisi dispossessed 
the animals of their land and subsequently excluded them from the use of productive land. Similar to the way that Ahab was less concerned about Naboth's dependence on land for his economic well-being, the Xhosa folktale shows that isisi was not interested in the well-being of the animals who rightfully owned the land. Noteworthy, although a present rereading of the Bible entails drawing parallels between the biblical texts and modern (con)texts, teasing out points of divergence is equally important. For instance, on the one hand, Ahab presented Naboth with an offer to purchase the land whilst on the other hand isisi took the land when the other animals went to the mountains to eat leaves (cf. $1 \mathrm{Ki}$ 21:1-2; Andersen 1966:48; White 1994:70). The element of early capitalism that is displayed in the contention that it is God's will that human beings are 'free' and subsequently make into private property what was once common property (cf. Boer 2015:15; Grotius 2006:315-321), which in my view is related to the Xhosa folktale, is noticeable in the narrative of Naboth's vineyard. The prohibition on selling the land, which is an inheritance to someone outside the family, suggests that Naboth's vineyard belonged to his family. Therefore, the point that productive land was a common property holds. The case of land dispossession in the narrative of Naboth's vineyard thus shows the way Ahab made into private property what was once common property. It becomes clear that the conversion of common property into private property is present in both the Xhosa folktale and the narrative of Naboth's vineyard.

Because the Xhosa folktale mirrors the South African context, a word on the issue of capitalism in South Africa is in order. The capitalistic tendency that perpetuates self-enrichment, which is evident in the biblical text under investigation as well as in the Xhosa folktale, seems to be equally evident in the South African context. On the issue of self-enrichment in South Africa, Mtshiselwa (2015) had this to say:

the trend of self-enrichment in the BEE initiative contrasts with the idea of equitable sharing of resources because it promotes greed and the individualistic approach to the accumulation of wealth. (p. 269; cf. Bond 2000:33; Dunnigan, Fazaeli \& Spies 2005:8)

Furthermore, Mbeki (2009) presented reasons for the BEE initiative, which include:

Weaning of the $\mathrm{ANC}^{1}$ from radical economic ambitions ... provision of the oligarchs (white business persons) with prominent and influential seats at the high table of the ANC government's economic policy formulation ... and giving of the oligarchs and their companies the first bite at the government contract that interest them ... [sic]. (p. 68)

It becomes clear that the 'white oligarchs lost political power to the ANC élites while retaining or winning the economic power, in particular productive land' (Mtshiselwa 2015:90). As was the case in colonial and apartheid South Africa, the economy of post-apartheid South Africa is in the hand of the white businessmen and their families. In this case, colonial structures that mainly benefited the white economic oligarchs 1.African National Congress. remain a concern in present-day South Africa. However, the narrative of Jehu's revolution as well as the contribution of uFudwana in the folktale of Intsimi yeenyamakazana could offer liberating possibilities to the poor black people who lost their land to the colonial and racist white men in South Africa.

\section{A revolution betrayed or justice attained? Considering the Jehu revolution}

The prophecy of 1 Kings 21:17-29 against Ahab is fulfilled in Ahab's death (cf. 1 Ki 22:37f.) and in Ahaziah's death as well as:

in the revolution of Jehu in which the king (Ahab's son Joram) together with the 'seventy sons of Ahab' and Jezebel the queen mother were slaughtered in Jezreel and in Samaria (2 Kgs 9:110:11). (Cross 2000:86)

One may then ask: Does it therefore mean that justice for Naboth and his family was attained? Based on the folktale of Intsimi yeenyamakazana, the point that Jehu did not redistribute Naboth's vineyard to his family becomes a concern. Unlike uFudwana, who restored the land to the dispossessed animals, it appears that Jehu probably took the land for himself. Sweeney (2007) remarked:

The site of Jezreel is identified with Zerin/Tel Yizra'al, located fifteen kilometres east of Megiddo at the eastern entrance to the main Jezreel Valley between Mount Gilboa to the south and Givat ha-Moreh to the north. This location is strategic, both because the rich farmland of Jezreel constitutes the breadbasket of ancient Israel and because its low-lying plains from the highway that links the Transjordan with coastal plain ... Excavation points to extensive building and fortification in the mid-ninth century B.C.E., which indicates that it was built up by the Omride dynasty .... (p. 247; cf. Mtshiselwa 2014:222)

Based on the preceding remark, specifically the description of Jezreel, it is thus clear that Naboth's vineyard was situated in a fertile area. Interestingly, in line with Sweeney and in contrast to Fritz, Franklin provides archaeological findings from the excavation in Tel Jezreel, in the Jezreel Valley, that provides a clue about a person who probably occupied Naboth's vineyard after his death (cf. Fritz 2003:211). For him, Phase III of the enclosure at Jezreel:

correlates with the post-Omride dynasty period and the 8th century B.C.E. casemate-walled acropolis of Building Period II at Samaria and with the stable and courtyard complexes of Stratum IV at Megiddo. (Franklin 2008:45, 51; cf. Mtshiselwa 2014:223)

Thus, not only do inferences from the preceding findings show that someone other than Ahab later occupied the land that was seized from Naboth, the archaeological findings also indicate that a person from the Jehu dynasty later occupied Naboth's land. Drawing on Franklin's argument, Mtshiselwa (2014) decisively argued:

If Franklin's claim is reliable, as I am inclined to assume, then archaeology suggests that after killing Ahab and his family Jehu probably did not redistribute the repossessed fertile land to Naboth's family but rather claimed it and subsequently passed it 
to his sons. This possibility shows that not all the land was redistributed to the original farmers in the Jehu revolution. As argued here, some land, obviously fertile in quality, was kept by those in power, for instance, the members of the Jehu dynasty. (p. 223)

Given the preceding argument, it makes sense to say that some of the dispossessed land was returned to the original owners by the élites whilst some land was retained for personal gains. The cases that reveal the return of the land to the original owner, such as that of the land or the city of Abel, lends the view that the Jehu revolution partly attained economic justice for the people who lost land. From a Marxist point of view, particularly with respect to overthrowing the imperialistic and capitalistic ruling élites by the proletariat as constituting justice (cf. Degenaar 1982:11), the point that Jehu's revolution partly attained economic justice is commendable. The readers of the Xhosa folktale would thus find the Jehu revolution attractive, as some of the dispossessed land is returned to the original owners with the view to restore the communitarian and familial mode of production. Moreover, in light of Mosala's trajectory, from which West, Masenya (ngwan'a Mphahlele) and Mtshiselwa, among others, draw their readings of the Hebrew Bible, the advancement of the interests of the poor in the Jehu revolution is plausible, as it is in line with the pursuit of social justice (Mosala 1997:57-58; Mtshiselwa 2014, 2015).

That Jehu probably took Naboth's vineyard provides a clue that may reasonably support the view that Naboth's family was denied economic justice. Thus, for the family that lost land and never regained it, the idea of a revolution betrayed would fit. Because Marxism is not entirely innocent in this way, it does not completely oppose capitalism because it is also a theory that is set to take over power, in a way similar to that displayed by the Jehu dynasty (cf. Degenaar 1982:27); one may thus have reservations about the Jehu revolution. Jehu overthrew the Omride dynasty, which was characterised by imperialism, and replaced it with a similar model of ruling. That the archaeological evidence suggests that Jehu took Naboth's land for himself shows the manner in which Jehu similarly served his personal interest. As stated earlier, a socio-anthropological reading of the ancient Near East that draws to light the accumulation of wealth, which involves 'the intangibles of rank and honour, power and privilege' (cf. Stansell 2006:93), may be relevant in the case of Jehu's revolution. In the pre-industrial context of ancient Israel, the reality of the acquisition of land and wealth by Jehu to consolidate his power and reign, is indisputable. Jehu failed to restore Naboth's vineyard to his family because of his probable desire to accumulate wealth and power, as was the norm for the likes of Omri and Ahab, among others.

The fact that $u F u d w a n a$ restored the land taken by isisi to the animals stands as a call for the redistribution of the land taken from all black South Africans during the colonial and apartheid period in the country. In addition, the point that uFudwana restored the stolen land to the animal family provides grounds (particularly on a hermeneutic level) to view Jehu's failure to restore Naboth's vineyard to his family as a betrayal of the revolution that was supposed to foster socio-economic justice. The socialist activism of $u$ Fudwana provides hope to the black South Africans who are confronted by the ideology of capitalism, which perpetuates selfenrichment tendencies that support an individualistic and privatised ownership of land.

\section{Implications for contemporary South Africa}

In the African context, Narratology and Orality underscore the value of socialisation, mental stimulation and memory preservation (Miruka 2004:182-189). In addition, the reason that the African people, specifically the elderly, narrated folktales and stories was to instil an enthusiasm for activism against injustice in South Africa. Not only does the Xhosa folktale of Intsimi yeenyamakazana mirror the South African situation of land dispossession during the colonial and apartheid regimes, it equally portrays the possibility of land redistribution. The fact that $u F u d w a n a$ restored the land to the animals calls for land redistribution in South Africa.

Of significance, firstly, is that the ideal of equitable sharing of resources embedded in the folktale of Intsimi yeenyamakazana, which is related to the ideology of socialism, produced the view that Ahab's actions exhibited an ideology of capitalism that stands in contrast to the communitarian and familial approach to land. The communitarian and familial ideology undergirds Naboth's understanding of the land, which for him belonged to his family. Secondly, the capitalist tendency to self-enrichment in Ahab draws one's attention to the same tendency in isisi, as well as the capitalist tendencies of both the white economic oligarchs and black political élites in South Africa. Thirdly, the point that uFudwana restored the dispossessed land to the animals triggers a concern about the way socio-economic justice was not completely attained in the story of Naboth's vineyard and Jehu revolution as well as in the South African context. Put differently, that many a person in the biblical and South African Narratology and Orality have not realised economic justice lends the idea that the revolution for socio-economic justice has been betrayed in both the biblical text and modern (con)texts.

Based on the narrative of Naboth's vineyard and Jehu's revolution as well as on the Xhosa folktale of Intsimi yeenyamakazana, the call for redistribution of the land dispossessed from all black South Africans during the colonial and apartheid period in the country becomes critical. The call is set to advance shared land resources in the mode of production in South Africa. Terreblanche noted that his book, titled 'A history of inequality in South Africa, 1652-2002', displays 'an attempt to help remember South Africa's past in a way that will inform its future' (Terreblanche 2005:3). This statement stresses the need to consider the legacy of the colonial and apartheid past of the country in the present discourse on land. As Terreblanche $(2005: 4,441)$ argued, socio-economic redress would take effect when the benefits of white South Africans from the colonial and apartheid past 
were acknowledged and radical redistribution of wealth from the rich to the poor was effected. This move would alleviate poverty and redress inequality. With respect to the colonial and apartheid South African past, Terreblanche observed that the seizure of productive land owned by the Xhosa people in the Eastern Cape between 1835 and 1853, which impoverished many Xhosa people, is an example of how the British colonists exploited the black population (Terreblanche 2005:385). It is interesting that in this case Terreblanche did not ascribe the exploitation of black people simply to 'the past' but specifically to the rule of the British colonists. The Natives Land Act of 1913 also sustained the impoverishment of many black South Africans in the colonial past, as it prohibited them from owning land outside the 'native reserves', which constituted 8.3\% of South Africa's land (Terreblanche 2005:260; cf. Modise \& Mtshiselwa 2013:359-378). The prohibition of black people from sharing crops and renting land for farming by white people restricted their economic activities (Terreblanche 2005:263-264). Terreblanche's contribution is valuable in that it explained that the poverty of black South Africans was induced by the economic policies of the colonial governments, such as the Natives Land Act of 1913, among others. The implications therefore of the reading of the Xhosa folktale of Intsimi yeenyamakazana and the narratives of Naboth's vineyard and Jehu's revolutions are that the legacy of apartheid that is manifested in the landlessness of many South Africans needs to be addressed. Worthy of note is the point that it is disturbing that the previously disadvantaged poor black South Africans continue to be poor, in an era in which the black political ANC élites who accumulate more wealth, are in power (cf. Mbeki 2009:93; Terreblanche 2012:71). Taking my cue from Leninism, although negotiations about liberation between the rich and poor often fail, it must be said that I am less sure about the direction that we need to take, particularly in reading the narrative of Naboth's vineyard and Jehu's revolution from a Marxist perspective and in light of the Xhosa folktale in the South African context, because of the violent nature of these texts. The violent revolution of Jehu and $u$ Fudwana may not be acceptable in a democratic country like South Africa, especially if one upholds the dignity of all human beings. However, the historic land dispossession, present landlessness and poverty of many black South Africans continue to be disturbing.

\section{Conclusion}

Reading the story of Naboth's vineyard and Jehu's revolution in light of Intsomi yamaXhosa proves to be relevant in African Biblical Hermeneutics. The article finds that an investigation of the Old Testament texts, particularly from an African Narratology/Orality and social perspective and developing and/or expanding African Biblical Hermeneutics is imperative. In addition, reading the Hebrew Bible from a socio-anthropological and economic perspective takes us beyond the impasse many scholars feel we have reached with regard to classical historical critical and literary interpretations of the Bible. Not only has the present article examined the light that the socio-economic function of the story of Naboth's vineyard and Jehu's revolution throws on the function of the folktale Intsimi yeenyamakazana and vice versa, it equally probed the socioeconomic implications that could be drawn from biblical and Xhosa Orality and Narratology for post-apartheid South Africa.

\section{Acknowledgements Competing interests}

The author declares that he has no financial or personal relationships that may have inappropriately influenced him in writing this article.

\section{References}

Aglietta, M., 2000, A theory of capitalist regulation: The US experience, Verso Books, London.

Andersen, F., 1966, 'The socio-juridical background of the Naboth incident', Journal of Biblical Literature 85(1), 46-57. http://dx.doi.org/10.2307/3264356

Boer, R., 1998, 'Remembering Babylon: Postcolonialism and Australian Biblical studies', in R.S. Sugirtharajah (ed.), The postcolonial Bible, pp. 24-48, Sheffield Academic Press, Sheffield.

Boer, R., 2015, The sacred economy of Ancient Israel, Westminster John Knox Press, Louisville, $\mathrm{KY}$

Bond, P., 2000, Elite transition: From apartheid to neoliberalism in South Africa, University of Natal Press, Pietermaritzburg.

Brenner, A., 1999, 'Ruth as a foreigner worker and the politics of exogamy', in A. Brenner (ed.), Ruth and Esther: A feminist companion to the Bible (second series), pp. 185-162, Sheffield Academic Press, Sheffield.

Brueggemann, W., 1975, 'Reflections on Biblical understandings of property', International Review of Mission 64(256), 354-361. http://dx.doi.org/10.1111/j. 1758-6631.1975.tb01195.x

Brueggemann, W., 2002, The land: Place as gift, promise and challenge in Biblical faith, Fortress Press, Minneapolis, MN.

Cone, J.H., 2007, 'Strange fruit: The cross and the lynching tree', Harvard Divinity Bulletin 35(1), 46-55.

Cone, J.H., 2011, The cross and the lynching tree, Orbis Books, Maryknoll, NY.

Cross, F.M., 2000, 'The themes of the Books of Kings and the structure of the Deuteronomistic History', in G.N. Knoppers \& J.G. McConville (eds.), Reconsidering Israel and Judah: Recent studies on the Deuteronomistic History, pp. 79-94, Eisenbrauns, Winona Lake, IN.

Degenaar, J.J., 1982, Marxism-Leninism and its implications for South Africa, H \& R Academia (Pty) Ltd, Pretoria.

Douglas, M., 1999, Leviticus as literature, Oxford University Press, New York.

Dunnigan, R., Fazaeli, K. \& Spies, J., 2005, Black economic empowerment - Difficulties and opportunities in making right the wrongs of the past, viewed 20 January 2014, http://faculty-course.insead.edu/dutt/emdc/projects/Sep-Oct05/Group_D.pdf

Fischer, I., 1999, 'The Book of Ruth: A 'feminist' commentary to the Torah?', in A. Brenner (ed.), Ruth and Esther: A feminist companion to the Bible (second series), pp. 24-49, Sheffield Academic Press, Sheffield.

Franklin, N., 2008, 'Jezreel: Before and after Jezebel', in L.L. Grabbe (ed.), The archaeology. Volume 1 of Israel in transition: From Late Bronze II to Iron IIa (c. $1250-850$ B.C.E.), pp. 45-53, T \& T Clark, New York.

Fritz, V., 2003, 1 \& 2 Kings: A continental commentary, transl. A. Hagedorn, Fortress Press, Minneapolis, MN.

Grotius, H., 2006, Commentary on the law of prize and booty, M.J. Van Ittersum (ed.), J Clarke (Trans.), Liberty Fund, Indianapolis, IN.

Heilbroner, R.L., 1962, The making of economic society, Prentice-Hall, Englewood Cliff,

Heilbroner, R.L., 1985, The nature and logic of capitalism, Norton \& Co, New York.

Kennedy, J.F., 1962, 86-Address on the first anniversary of the Alliance for Progress, viewed 24 June 2016, from http://www. presidency.ucsb.edu/ws/?pid=9100

Kinsler, R. \& Kinsler, G., 1999, The Biblical jubilee and the struggle for life, Orbis Books, Maryknoll, NY.

Klein, N., 2007, 'Democracy born in chains: South Africa's constricted freedom', in N. Klein (ed.), The shock doctrine: The rise of disaster capitalism, pp. 194-217, Metropolitan Books, Henry Holt and Company, New York.

Knight, D.A., 2011, Law, power and justice in ancient Israel, Westminster John Knox Press, Louisville, KY.

Lenin, V.I., 1964, 'The state and revolution', Lenin Collected Works 25, 385-497.

Lenin, V.I., 1972, 'The black hundreds and the organisation of an uprising', Lenin Collected Works 9, 200-204.

Lenski, G.E., 1966, Power and privilege: A theory of social stratification, University of North Carolina Press, Chapel Hill, NC. 
Mafico, T.L.J., 2012, 'Land concept and tenure in Israel and African tradition', in M Dube, A. Mbuvi \& D. Mbuwayesango (eds.), Postcolonial perspectives in African Biblical interpretations, pp. 235-244, Society of Biblical Literature, Atlanta, GA.

Malina, B.J., 1987, 'Wealth and poverty in the New Testament and its world', Interpretation 41(4), 364-367. http://dx.doi.org/10.1177/002096438704100403

Malthus, T.R., 2004, 'The unpublished papers in the collection of the Kanto Gakuen University', J.P. \& T.H. Parry (eds.), Cambridge University Press, Cambridge.

Masenya (ngwan'a Mphahlele), M., 2004, 'Struggling with poverty/emptiness: Rereading the Naomi-Ruth story in African-South Africa', Journal of Theology in Southern Africa 120, 46-59.

Masenya (ngwan'aMphahlele), M., 2009, “"For better or for worse?” - The (Christian) Bible and Africana women', Old Testament Essays 22(1), 126-150.

Masenya (ngwan'a Mphahlele), M., 2010, 'Is Ruth the 'Eshet Hayil' for real? An exploration of womanhood from African proverbs to the threshing floor (Ruth 3:1-13)', Studia Historiae Ecclesiasticae 36, 253-272.

Mbeki, M., 2009, Architects of poverty: Why African capitalism needs changing, Picador Africa, Johannesburg.

Miruka, O., 2004, Encounter with oral literature, East African Educational Publishers, Nairobi.

Modise, L. \& Mtshiselwa, N., 2013, 'The Natives Land Act of 1913 engineered the poverty of black South Africans: A historico-ecclesiastical perspective', Studia Historiae Ecclesiasticae 39(2), 359-378

Mosala, I.J., 1997, 'Ownership or non-ownership of land forms the basis of wealth and poverty: A black theological perspective', in G. Mongezi \& L.A. Milton (eds.), An African challenge to the church in the twenty-first century, pp. 57-64, South African Council of Churches, Cape Town.

Mosala, I.J., 2006, 'The implications of the text of Esther for African women's struggle for liberation in South Africa', in R.S. Sugirtharajah (ed.), The postcolonial Biblical reader, pp. 134-141, Blackwell Publishing, Oxford.

Mtshiselwa, N., 2014, 'A re-reading of 1 Kings 21:1-29 and Jehu's revolution in dialogue with Farisani and Nzimande: Negotiating socio-economic redress in South Africa', Old Testament Essays 27(1), 205-230.

Mtshiselwa, V.N.N., 2015, 'Re-reading the Israelite Jubilee in Leviticus 25:8-55 in the context of land redistribution and socio-economic justice in South Africa: An African liberationist perspective', Unpublished PhD thesis, University of South Africa, Department of Biblical and Ancient Studies, Pretoria.
Nam, R.S., 2012, Portrayals of economic exchange in the Book of Kings, Brill, Leiden.

Ndibongo, W.P.T. \& Ntloko, E.N., 1990, Ezinye lintsomi zamaXhosa, Varia Books, Johannesburg.

Nihan, C., 2007, From Priestly Torah to Pentateuch: A study in the composition of the Book of Leviticus, Mohr Siebeck, Tübingen.

Olojede, F., 2013, 'Women and the cry for justice in Old Testament court narratives: An African reflection', Old Testament Essays 26(3), 761-772.

Römer, T., 2005, The so-called Deuteronomistic History: A sociological, historical and literary introduction, T\&T Clark International, London.

Schmid, K., 2012, The Old Testament: A literary history, Fortress Press, Minneapolis, MN.

Stansell, G., 2006, 'Wealth: How Abraham became rich', in P.F. Elser (ed.), Ancient Israel: The Old testament in its social context, pp. 92-110, Fortress Press, Minneapolis, MN.

Sweeney, M.A., 2007, I \& II Kings: A commentary, Westminster John Knox Press, Louisville, KY.

Terreblanche, S.J., 2005, A history of inequality in South Africa, 1652-2002, University of Natal Press, Pietermaritzburg.

Terreblanche, S.J., 2012, Lost in transformation: South Africa's search for a new future since 1986, KMM Review Publishing Company, Johannesburg.

Volschenk, G.J., 2004, 'The land: Primary category of faith', Hervormde Teologiese Studies 60(1), 625-639. http://dx.doi.org/10.4102/hts.v60i1/2.496

West, C., 1981, 'The North American blacks', in S. Torres \& J. Eagleson (eds.), The challenge of basic Christian communities: Papers from the International Ecumenical Congress of Theology, February 20-22 March, 1980. Säo Paulo, Brazil, pp. 255-257, Orbis, Maryknoll, NY.

West, G., 2011, 'Tracking an ancient near Eastern economic system: The tributary mode of production and the Temple-State', Old Testament Essays 24(2), 511-532.

West, G.O., 2014, 'Locating "contextual Bible study" within biblical liberation hermeneutics and intercultural biblical hermeneutics', HTS Teologiese Studies/ Theological Studies 70(1), 1-10. http://dx.doi.org/10.4102/hts.v70i1.2641

White, M., 1994, 'Naboth's Vineyard and Jehu's coup: The legitimation of a dynastic extermination', VetusTestamentum 44(1), 66-76. http://dx.doi.org/10.1163/ $156853394 \times 00060$ 